\title{
Understanding the Nature and Market for Islamic Financial Products
}

\author{
Farhana Newaz \\ Victoria University of Wellington, New Zealand \\ Revti Raman \\ Victoria University of Wellington, New Zealand \\ Kim-Shyan Fam \\ Victoria University of Wellington, New ZealandUniversity of South Carolina Aiken
}

\begin{abstract}
The rapid growth of Islamic finance during the last 10 years across regions for various Islamic Financial Products (IFPs) provides opportunities and challenges to managers and researchers. Muslims who constitute about one fourth of the world population constitute a huge potential markets for IFPs. IFPs are getting popular even among non-Muslims. The geographic distribution of IFPs is skewed to the Gulf and North African countries while Asia presents a huge untapped potential. The paper provides an understanding of the nature and market for IFPs which could be useful to managers and researchers to undertake their marketing and research endeavours.
\end{abstract}

Key Words: Islamic finance, Shariah-compliant products, Islamic Financial Market, Ethical finance

\section{Introduction}

Significant developments have taken place in Islamic finance during last 50 years. The Islamic finance has moved from providing retail and commercial banking during 1970s to advanced treasury services, balance sheet management and innovative asset management more recently (IFSB, IDB, and IRTI, 2010). Though the Islamic financial services industry currently represents approximately only $1 \%$ of global assets, it has been growing by more than $30 \%$ annually over the last 10 years (Wyman, 2009). Currently, more than 600 Islamic financial institutions (IFIs) are operating across 100 countries worldwide and the global Islamic finance assets are expected to reach US\$ 1.6 trillion by 2012 (ACC and KPMG, 2012; Aziz, 2012; GIFF, 2012). Islamic finance has become an integral part of the global financial system with a huge potential market, in particular to the 1.5 billion Muslim worlds. Most of the current demand for Islamic financial products (IFPs) is in the Middle East and North Africa with Asian countries next in the queue. A range of IFPs have emerged which are directly competing with conventional financial products (CFPs) in 
most of the Muslim countries. Moreover, IFPs are getting attraction of non- Muslim communities as well (Zaher and Hassan, 2001). Over the last 50 years Islamic finance has established itself as an alternate method of investment. Considering the significance of Islamic finance, this papers aims to provide an understanding of the nature and market potential of Islamic finance. The paper also calls for undertaking empirical investigations into the regions such as Asia, which are not well represented in the current research but hold good potential for Islamic financial products.

Rest of the paper is organised as follows. Section two clarifies the nature and concept of Islamic finance and distinguishes it from conventional financing system. The next section discusses the types of IFPs followed by a section on the global market of IFPs. Implications for business practice are provided in the last section.

\section{Nature of Islamic Financial Products}

Financial products, in general, refer to the instruments that help save, invest, and get insurance or borrowing facilities (Obaidullah, 2005). Islamic financial product may be described as a financial service or product principally implemented to comply with the main tenets of Shariah or Islamic law on interest, non-Islamic investments, and speculation (Gait and Worthington, 2008; Gait and Worthington, 2009). IFPs are based on Islamic Laws and they significantly differ from the CFPs in a number of ways (Iqbal, 1997; Khan and Bashar, 2008; NBR, 2008). CFPs include interest payments whereas any predetermined payment over and above the actual amount of principal is prohibited in IFPs. As per the Islamic law, the lender must share in the profits or losses arising out of the enterprise for which money was lent. Moreover making money from money is not acceptable by Islamic law. Money is only a medium of exchange, and therefore should not be allowed to give rise to more money, via fixed interest payments, simply by being put in a bank or lent to someone else. The Islamic law also prohibits uncertainty, risk or speculation (Gharar) and thus insurance products which are quite common in CFPs. Any investments support practices or products that are not forbidden (or discouraged) by Islam.

Islamic finance system has its own peculiar merits which many times are lacking in the conventional financial system. For instance, under Islamic system the profitsharing channels investible funds to the projects with the highest expected profitability as opposed to the interest-based system where funds go to the most creditworthy borrowers whose projects may not necessarily be the most profitable ones. This results in the end result of allocation of goods and services that serves society's collective interests in the best possible manner. Moreover, profit-sharing is more contributing to economic growth because it would increase the supply of risk capital for investment and better incentives for undertaking such risks due to expected profitability. Thus the Islamic system promotes an 'integrated' economic development as it persuades the use of money for facilitating trade in goods and investment in productive capacity rather than creating money for the sake of money. This structure of Islamic finance is likely to be more stable and less risky to financial crisis which can be source by speculative activities.

\section{Types of Islamic Financial Products}


The reason for existence of a financial system is to transfer funds from savings surplus units (SSU) to savings-deficit units (SDU) in the economy which assist intermediation between savers and investors. This process involves use of financial products and services that's created and provided by financial institutions. Most of the service marketing literatures put efforts to classify services using different criteria such as how a service may be customized for the customer or how the service is differentiated (Kasper, van Helsdingen, and Gabbott, 2006). While attempting to categorize services, it becomes clear that financial services vary extremely. Financial services can be classified based on the nature of the service and to whom it is being supplied (Doyle, 2002). The issue that combines financial services is that they are often tough to evaluate, they are offered through a range of delivery systems, there is opportunity for co-production and they are generally acquired as a means of achieving an end (Farquhar and Meidan, 2010). As shown in Figure 1, broadly IFPs can be classified into four categories in terms of approaches of financing that satisfy particular financial need of the customers: deposit products, credit products, capital market products and insurance products (www.Ifsb.org).

\section{Figure 1: Categories of Islamic Financial Products}

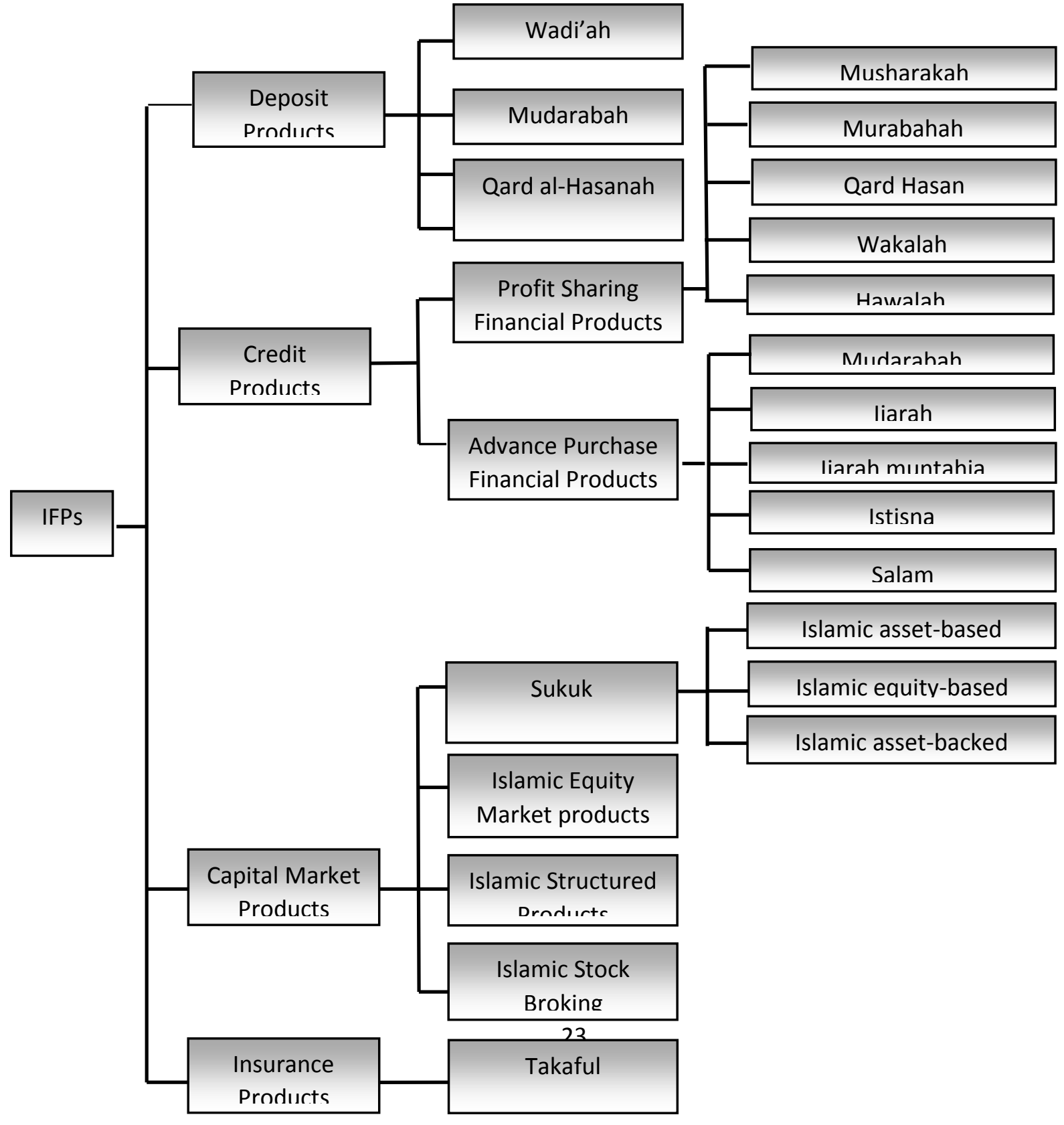




\section{Deposit Products}

Deposit products satisfy people's need of money in crisis period, as the customers can save some money or fund through such products (e.g. current account, savings account, term deposit and savings bond). These products are based on revenuesharing which is usually calculated ex post on a monthly basis. Islamic financial institutions are engaged in mobilizing savings from group of Muslim savers by offering Shariah compliant products that also vary with respect to other dimensions of return, risk, liquidity, maturity, safety, stability and the like (Obaidullah, 2005). There are primarily three types of deposit products available: Wadi'ah, Mudarbah, and Qard al-Hasanah. Wadi'ah deposits include current accounts (giro wadi'ah) while Mudarabah deposit products are based on revenue-sharing between depositor and bank, including savings products that can be withdrawn any time and time deposit products. Qard al-Hasanah, on the other hand, are unremunerated deposit products, usually for charitable purposes. These Islamic deposit products allow no trade-off in the matter of Shariah-compliance.

\section{Credit Products}

Credit products satisfy people's borrowing needs and are based on profit-sharing, either at a mutually agreed-upon ratio or at a mutually agreed-upon fixed rate. These products are backed by collateral as collateral-free lending would normally be considered as containing a speculative element, or moral hazard. People can spend more money, than they can earn through credit products (e.g. loans, hire purchase, leasing and mortgage). In this category IFPs can be categorised as 1) profit sharing financial products and 2) Advance purchase financial products.

\section{Profit Sharing Financial Products}

Profits sharing products may include active partnership (Musharakah) or passive partnership (Mudaraba). In case of Musharakah capital is provided by the bank in return for a share in the realized profit (or the loss if a loss occurred). In diminishing musharaka, the bank is entitled to receive, in addition to its share in realized profits, an extra payment that is specifically assigned for the purpose of reducing its share in the company's capital until this is fully paid off by the partner. Mudarabah on the other hand is a contract between two parties; a capital-owner (who contributes capital) and an investment manager (who provide entrepreneurship). Profit is shared between parties on a pre-agreed ratio at the time of contract. These two modes provide an alternative banking and if implemented on a national level are likely to result in much fairer distribution of wealth in society with a far reaching effect on the economy (Kahf and Khan, 1993).

Other forms of credit products include Qard Hasan, Wakalah and Hawalah. Qard Hasan is a charitable loan free of interest and profit-sharing margins. The loan is repaid in instalments and a modest service charge is permissible. In case of Wakalah, a bank is authorized to conduct business on customers' behalf. Hawalah, on the other hand is an agreement by the bank to undertake some of the liabilities of the customer in return for a service fee. The customer pays back the bank when the liabilities mature (Obaidullah, 2005). 


\section{Advance Purchase Financial Products}

Advance purchase financial products include Murabahah, Ijara, Ijarah muntahia bittamleek, Istisna, and Salam. Murabahah is a spot sale contract where the client (the bank's customer) orders the purchase of a certain commodity that is available either in the domestic or the foreign market at a specified cash price which include a profit margin (mark-up) in favour of the bank. If the customer's creditability is satisfactory, the bank buys the commodity. The bank accepts payment for the commodity in instalments, which usually stretch over one year or more. When Murabahah purchase is made by means of importation from foreign markets, letters of credit and foreign conventional banks are involved, necessary shariah precautions are taken to avoid payment of interest at any step (Gait and Worthington, 2008; Gait and Worthington, 2009).

Ijarah is an Islamic alternative to Leasing. Literally, Ijarah mean to give something on rent. Therefore Ijarah is a leasing contract under which a bank buys and leases out equipment required by its clients for a rental fee. The bank (lessor) and the client (lessee) mutually agree on the leasing period, and terms of payment. Risk and rewards of ownership lie with the bank i.e. any loss to the asset beyond the control of the client (lessee) should be borne by the bank (lessor). Maintenance and insurance of the leased asset are the bank's responsibility, whereas the lessee has to bear the running costs as well as any repair costs in the case of misuse (Gait and Worthington, 2007).

Ijarah muntahia bittamleek can be understood as a lease ending with ownership. It is a financing contract which implies a promise on the part of one party (the bank) to gift or to sell the leased asset at a nominal price at the end of the lease term to the client (lessee). As shariah law does not allow for the combination of leasing and ownership in one single contract, this second transfer of ownership contract should be signed only after the termination of the lease term as promise by the bank (lessor).

Istisna is a manufacturing contract in which a party orders another to manufacture and provide a commodity, the description of which, delivery date, price and payment date are all set in the contract. For example, a household that wishes to build a house, or a firm that needs to construct a building, or to manufacture equipment with particular specifications, would approach the bank for this purpose. After assessing the economic viability of the operation and the creditability of the customer, an istisna contract is signed between the two parties. As this type of contract is of a binding in nature, the customer submits a down payment and undertakes to pay the remaining part of the manufacturing price, as mutually agreed with the bank, in instalments over a given period of time. The Islamic bank would then sign a parallel istisna contract whereby it extends finance to a firm that agrees to manufacture the requested object according to specification and to deliver it at an agreed future date. Islamic banks in the Arab Gulf countries have used this type of contract successfully to finance big operations, particularly in the construction sector and infrequently in the industrial sector (Ahmad, 2010). 
Salam is a contract to sell a prescribe commodity where price is paid in advance at the time of contracting against delivery of the purchased goods or services at a specified future date. Salam is permissible in shariah to meet the instant cash needs of a seller who undertakes the future delivery of the commodity. Thus, banking finance is extended to firms or individuals against their commitment to deliver commodities at future dates. To hedge the salam operation banks also practice parallel salam. This involves making counter deals with other parties whereby they obtain immediate cash payments against a commitment to deliver commodities of similar quantity and quality to those in the salam contracts at some future date. Islamic banks in Pakistan, Sudan, and in some Arab Gulf countries have practiced salam transactions (Ahmad, 2010).

\section{Capital Market Products}

Capital market products satisfy customers' investment need with the expectation of earning a favourable return. These products are based on the same principles as credit products. The long term funds are raised through capital market products which are conducted by both financial institutions and governments (e.g. share, securities, bond, treasury etc.). Haider and Azhar (2010) identifies the following main IFPs in this category.

\section{Sukuk Market products}

Sukuk are the most important and most prominent elements of Islamic capital market. In Sukuk market financing is backed up by assets, equity, and asset based securities. In Islamic economics, financing is based on the specific asset. In Islamic finance money is considered to be just a medium of exchange or a mechanism to complete the transaction. While in case of conventional finance this is not always the case and most of the time financing is currency-based. Equity-based financing in Islamic model is based on the sharing of business risks, as well as rewards by the bank and its client. Both parties contribute for the basic ingredients of a business venture such as capital, management, know-how, labor, and other related professional attributes. Profits are distributed based on an agreed profit distribution ratio while losses are prorated to each party's capital participation. Equity financing is cemented by entering in either one of two contracts, namely a partnership contract and a trust financing contract. Shariah-compliant asset-backed securitization (ABS) delivers a risk-return profile similar to a conventional structure. However, conventional securitization was developed in non-Islamic economies and invariably involves interest-bearing debt.

\section{Other Capital Market Products.}

Other Islamic capital market products include equity market products, structured products and stock broking. Islamic equity market operates on the basis of equity participation by the investor. It includes the Islamic products like Shariah-compliant stocks, Islamic unit trusts, Islamic REITs (Real estate investment trusts) and Islamic index. Islamic structured investment products are customized products according to the need of the specific investor which can be a wealthy individual or a group of investors. The risk and reward of these products are designed to meet a specific objective. Generally two types of Islamic structured products are used in Islamic 
capital market; Dual currency structured Investment and Equity linked structured investment. In Islamic capital market, stock broking is done according to the Shariah principals. This part of Islamic capital market deals with Shariah-compliant trading and Shariah-compliant margin financing.

\section{Insurance Products}

Insurance products allow individuals, businesses and other entities to protect themselves against significant potential losses and financial hardship. People who want to protect themselves or someone else against financial hardship are considering insurance products (e.g. general and life insurance) (Gait and Worthington, 2009; Imady and Seibel, 2006). Many insurance companies have been established to offer Muslim individuals and business with insurance coverage. Islamic insurance is the mechanism through which the participants donate part or all of their contributions which are used to pay claims for damages suffered by some of the participants (Mayasami and Kwon, 1999). One key Islamic insurance product is Takaful - Islamic insurance with joint risk-sharing. Muslim jurists have agreed that Takaful schemes are accepted by Islamic Shariah because it encompassing the elements of shared responsibility, joint indemnity, common interest and solidarity (Billah and Patel, 2003).

Based on the discussion in the above two sections a comparison of IFPS and CFPs can be summarised as under:

1. Deposit products: reward is fixed and predetermined in case of CFPs while it is variable in IFPs and is accepted through Musharaka and Mudaraba.

2. Deposit products: IFPs share both the risk and reward with depositors while in case of CFPs total risk is born by the bank and total reward belongs to it after servicing the depositor at a fixed rate.

3. Credit products: CFPs provide credit facility by charging interest where as IFPS are based on profit sharing, either at a mutually agreed upon ratio or at a mutually agreed upon fixed rate.

4. Capital market products: IFPs invest to create required liquidity at the same time to earn some revenue by investing in short term and liquid securities. However, investment in government securities, short term loans, bonds and money at call and short notices is forbidden because of interest based transactions. CFPS on the other hand have many avenues to maintain liquidity including government securities, shorter term loans and money at call and short notices, leasing companies' bonds, investment in shares etc.

5. Insurance products: IFPs eencompass the elements of shared responsibility, joint indemnity, common interest and solidarity whereas CFPs aim at an effective risk transfer mechanism by which individuals or organisations can exchange their uncertainty of financial loss (or risk) for the certainty of the premium 


\section{Market for the Islamic Financial Products}

IFPs have been directly competing with CFPs in most of the Muslim countries. These Islamic financial products have achieved attractiveness for their competitiveness and efficiency not only by the Muslim people but also with the non-Muslim communities (Zaher and Hassan, 2001). Islamic finance has established itself as an alternate method of investment (Ali, 2008). It is considered as ethical finance i.e. not investing in unethical practices and industries (Maurer, 2001; Wilson, 1997). Significant developments have occurred in in Islamic finance during the last 50 years (Figure 2).

Figure 2: Significant Developments in Islamic Finance

\begin{tabular}{|c|c|c|c|c|}
\hline $\begin{array}{l}\text { Prior to } \\
1970 s \rightarrow\end{array}$ & $1970 s \rightarrow$ & $1980 s \rightarrow$ & $1990 s \rightarrow$ & Contemporary $\rightarrow$ \\
\hline $\begin{array}{l}\text { Primarily } \\
\text { Retail Banking }\end{array}$ & $\begin{array}{l}\text { Commercial } \\
\text { Banking }\end{array}$ & $\begin{array}{l}\text { Property Finance } \\
\text { and syndication } \\
\text { Islamic Insurance } \\
\text { (Takaful) }\end{array}$ & $\begin{array}{l}\text { Equity Funds } \\
\text { Leasing } \\
\text { Islamic } \\
\text { Securitisation }\end{array}$ & $\begin{array}{l}\text { Advanced } \\
\text { Treasury Services } \\
\text { Balance Sheet } \\
\text { Management } \\
\text { Innovative Asset } \\
\text { Management }\end{array}$ \\
\hline
\end{tabular}

Source: (IFSB, et al., 2010)

Since 1960s, the IFPs evolved from a "fringe industry" that provided to the specific banking requirements of the Muslim community to a global industry incorporating banking, insurance and capital market. The first Islamic finance applications and practices were offered in Egypt and Malaysia during 1960s. The institutions offering Islamic financial services (IIFS) were proposed for operational mechanisms and a number of books were published on Islamic banking during the following years. During 1970s, Islamic banks appeared with the formation of Dubai Islamic Bank and the Islamic Development Bank (IDB). Besides, religious objections to conventional insurance became prominent, placing the ground for an alternative structure in 1975. The first takaful company has started its operation in 1979. During 1980s, more Islamic banks and academic institutions developed in a number of countries and Islamic mutual funds and other non-banking financial institutions emerged towards the middle of the 1980s. In 1990s, the Accounting and Auditing Organization for Islamic Financial Institutions (AAOIFI) was established and its first standards were issued. The advancement of Islamic banking products increased and reputed international conventional banks started operating Islamic windows. At the same time, the Dow Jones and Financial Times Islamic indexes were introduced. Systemic concerns, regulation, supervision and risk management issues all together assembled momentum for Islamic financial services. Commercial event organizers exposed Islamic banking and financial activities as a source of attractive business. As alternatives of conventional bonds, sovereign and corporate sukuk has emerged and are increasing rapidly in volume during the time period of 2000 and onwards. International Islamic financial infrastructure institutions as well as other commercial support institutions and the Liquidity Management Centre (LMC) were established. The systemic importance of Islamic banks and financial institutions is widely recognized. 


\section{Growth Trends}

The industry has grown rapidly during the last decade with about three times growth just in the last 5 years (Figure 3). The total global assets of Islamic finance was US\$ 531 billion at the end of 2006, whereas it was estimated US\$ 700 billion at the end of 2007 with the combined revenue of US\$ 53 billion, profits totalled US\$15 billion and is expected to more than double to US\$ 32 billion over the next 5 years (IFSB, et al., 2010; Novethic, 2008; Wyman, 2009). The rapid growth of Islamic finance indicate its ability to meet the changing pattern of demand by consumers and businesses, its competitiveness and its survival in the more challenging market. This trend has fostered the conventional financial institutions from the developed economies to involve them in Islamic financial market.

Figure 3: Industry Growth over the

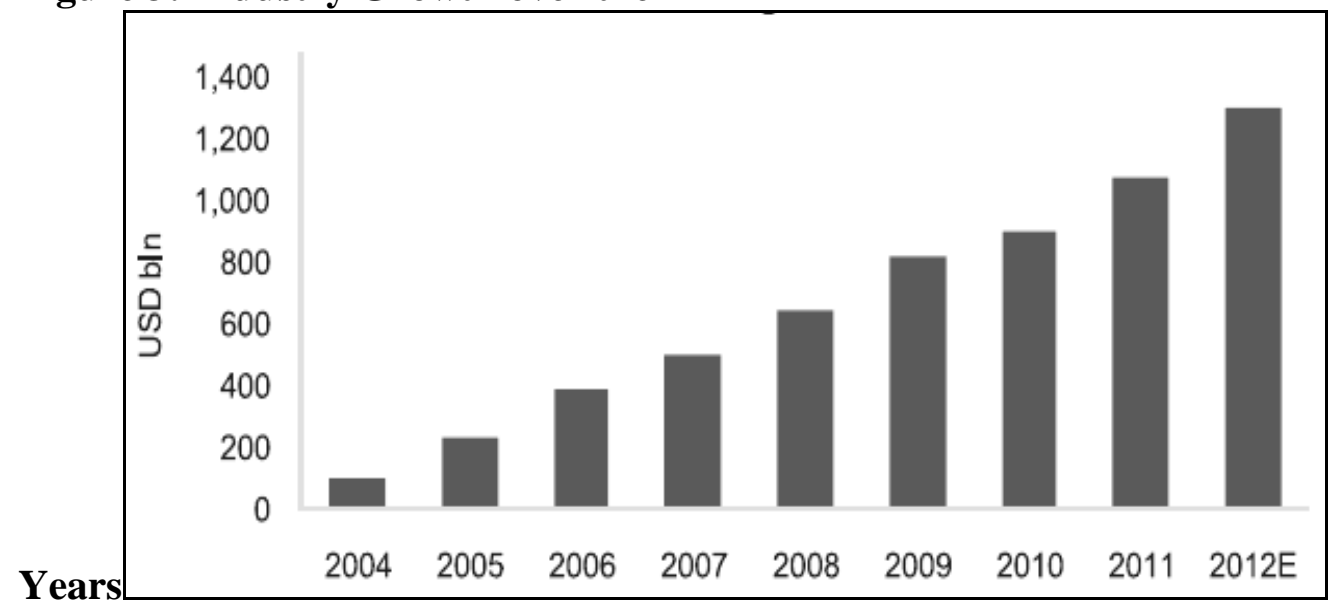

Source: IFISB (2013)

The main reasons for the industry growth include: the strong demand from a large number of immigrant and non-immigrant Muslims for Shariah-compliant financial services and transactions; second, the growing oil wealth, with demand for suitable investments soaring in the Gulf region; and third, the competitiveness of many of the products, attracting Muslim and non-Muslim investors (El-Qorchi, 2005). Moreover, a large number of key financial institutions worldwide have re-designed their conventional products as Shariah-compliant products in recognition of the growing importance of Islamic finance. The financial crisis also caused a lot of interest in Islamic finance as a form of financial intermediation that can perhaps promote financial stability. Islamic finance is viewed as fundamentally stable since it avoids interest and interest based assets, focuses on equity as opposed to debt, and restricts speculation. Another issue that Islamic finance is receiving increasing attention worldwide because of the role conventional financial institutions performed during the global financial crisis (Nasr, 2011).

\section{Industry Composition}

The Islamic financial services industry comprises an increasingly diverse range of institutions, including commercial and investment banks, mutual insurance (Takaful) 
and investment companies. Banks, however, remain the core of the financial services industry in many countries and offshore financial centres since they account for the bank for financial transactions and their soundness is of key concern for systematic liability (Sundararajan and Errico, 2002). The assets of Islamic finance consist of all these Islamic banks, Islamic investment firms, sukuk issues, funds and Takaful institutions (Figure 4).

Figure 4: Global Assets of Islamic Finance

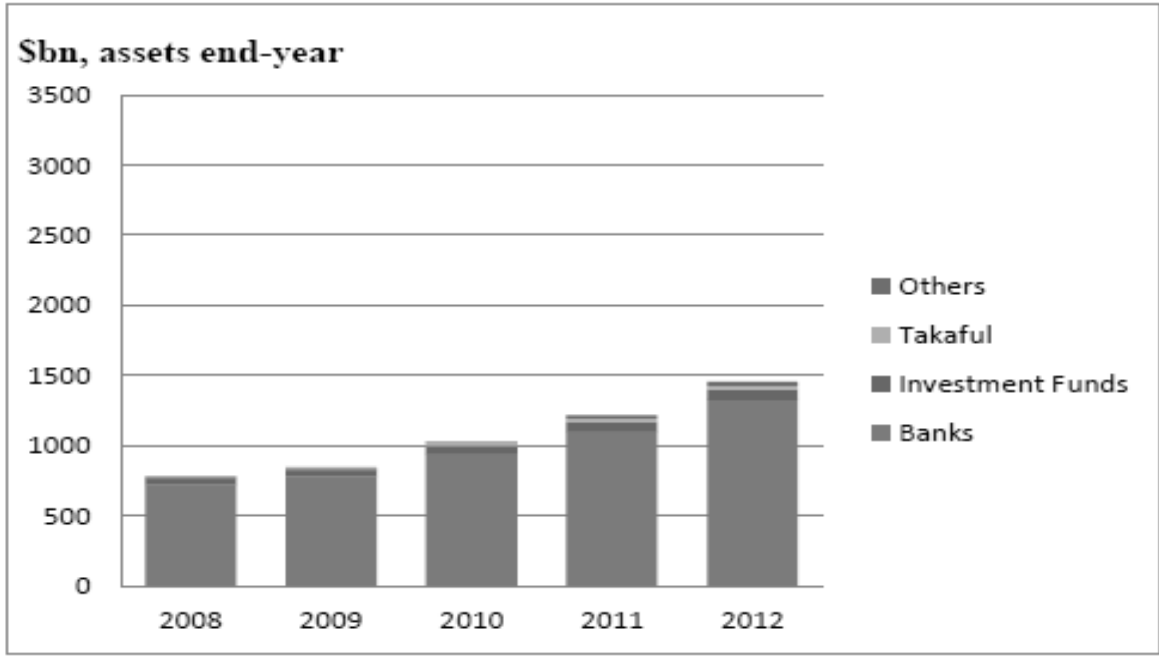

Source: The UK Islamic Finance Secretariat (UKIFS, 2012)

Islamic banking assets represent a predominantly higher share of $81 \%$ in the overall size of the global Islamic finance industry. On the other hand, Sukuk issues accounted for $13.4 \%$. As far as the Islamic investment activity is considered, it is observed that, Islamic investment firm assets represent $4.5 \%$ of the industry's assets and takaful sector captures $1.1 \%$ of total Islamic finance assets. The total Islamic banking assets were US $\$ 463$ billion at the end of 2006 and US\$660 billion at the end of 2007 which indicates strong growth. Assets held by fully Shariah-compliant banks including Islamic banking windows of conventional banks rose by $21.4 \%$ to US $\$ 1048$ billion, from US $\$ 863$ billion in 2010 (Banker, 2009). Islamic securities or Sukuk market grew from US\$ 6 billion to US\$24 billion between 2004 and 2007 but registered a decline of about $30 \%$ in 2008 due to the uncertainty in the global capital markets (Tayyebi, 2009). However, the sukuk market rebounded in the second half of 2009 and its prospective is evident from the active participation of global players like international investment banks, Islamic banks and securities firms that have participated in the issuance of sukuk. The total asset of Islamic fund was estimated US\$58 billion in 2010 which rose by $7.4 \%$ from US $\$ 54$ billion in 2009 . Takaful assets have increased from US\$13 billion in 2009 to over US $\$ 21$ billion in 2010. Takaful continues to record rapid growth in new and existing markets globally (IFSB, et al., 2010).

\section{Geographical Mandates}

Islamic finance operations are mainly concentrated in the Middle East and Southeast Asia, but are also appearing in Europe and the United States (El-Qorchi, 2005). The geographic mandates of IFPs are shown in Table 1. With $6 \%$ of the global Muslim population, the Gulf Cooperation Council (GCC) region accounts for $40 \%$ share of the \$1.1trillion global Islamic finance industry with majority of the growth in absolute 
terms. The growth of Islamic finance in the late 1970s concurred in GCC with the two oil shocks of that decade, which created a huge amount of wealth (Hamzeh, 2009). In recent years, the development of the financial sector in the GCC has been unprecedented with the development of financial centers that have attracted global financial institutions (Ahmedji, 2011). Middle East and North Africa (MENA) region are home to the majority of the global Islamic finance assets with a total share of $39 \%$ in 2011 comprising with $22 \%$ of the global Muslim population. Strong regulatory support and political will that stand out the growth of Islamic finance in the MENA region even more than demand by the society for Islamic finance (Ali, 2011). A range of Islamic financial products has been developed in Asia that was powered by the twin drivers of the resident Muslim populations in the region and the arrival of Middle Eastern businesses, banks in Southeast Asia are being pushed to offer an increasingly wide range of financial product (Venardos, 2006). Though the majority of Muslim people lives in Asia with $41 \%$ global Muslim population, but the industry is represented inadequately with a relatively small share of $15 \%$, which in turn suggests a great prospective of massive growth in the region. Conversely Australia, Europe and America hold a collective share of $5 \%$ in the global Islamic finance market as a large non-Muslim region. Consisting of $26 \%$ of world Muslim population, the Sub-Saharan African (SSA) countries with $1 \%$ of global Islamic financial assets face large funding gaps particularly in the area of infrastructure and not getting the opportunity to tap into the Islamic finance market which is expanding as a new source of funding for large infrastructure development projects (OIC, 2012).

Table 1: Breakdown of Islamic Assets by Institution and Region (2012)

\begin{tabular}{|l|l|l|l|l|l|l|l|l|}
\hline Region & $\begin{array}{l}\text { Banking } \\
\text { Assets } \\
\text { (USD } \\
\text { billion) }\end{array}$ & $\begin{array}{l}\text { Sukuk } \\
\text { Outstan } \\
\text { ding } \\
\text { (USD } \\
\text { billion) }\end{array}$ & $\begin{array}{l}\text { Islamic } \\
\text { Fund } \\
\text { Assets } \\
\text { (USD } \\
\text { billion) }\end{array}$ & $\begin{array}{l}\text { Takaful } \\
\text { Assets } \\
\text { (USD } \\
\text { billion) }\end{array}$ & $\begin{array}{l}\text { Total } \\
\text { Islamic } \\
\text { Finance } \\
\text { Assets (USD } \\
\text { billion) }\end{array}$ & $\begin{array}{l}\text { Market } \\
\text { Share }\end{array}$ & Population & $\begin{array}{l}\text { GDP } \\
\text { at } \\
\text { PPP } \\
\text { USD }\end{array}$ \\
\hline Asia & 171.8 & 160.3 & 22.6 & 2.7 & 357.4 & $22.5 \%$ & $41 \%$ & 3,731 \\
\hline GCC & 434.5 & 66.3 & 28.9 & 7.2 & 536.9 & $34 \%$ & $6 \%$ & 10,94 \\
\hline $\begin{array}{l}\text { Mena } \\
\text { (exc. } \\
\text { GCC) }\end{array}$ & 590.6 & 1.7 & 0.2 & 6.9 & 599.4 & $38 \%$ & $22 \%$ & 4 \\
\hline $\begin{array}{l}\text { Sub- } \\
\text { Saharan } \\
\text { Africa }\end{array}$ & 16.9 & 0.1 & 1.6 & 0.4 & 19 & $1 \%$ & $26 \%$ & 2,075 \\
\hline Others & 59.8 & 1.0 & 10.8 & 0.0 & 71.6 & $4.5 \%$ & $5 \%$ & 6,528 \\
\hline Total & 1273.6 & 229.4 & 64.2 & 17.2 & 1584.4 & $100 \%$ & $100 \%$ & \\
\hline
\end{tabular}

Notes: Figures may not add up to the totals due to rounding effect, Others include Europe and North America, GCC: Qatar, Bahrain, Kuwait, UAE, Saudi Arabia, and Oman

Sources: GIFF (2012), IDB (2012)

It is clear from Table 1 that MENA region has the maximum number of Islamic banking assets of US $\$ 462.6$ billion as the majority of Islamic banks are in the MENA region and are part of private sector which exists along with the conventional financial institutions. Conversely, Asia captures majority share of Sukuk and Islamic investment fund assets of US $\$ 120.8$ billion and US $\$ 16.2$ billion respectively. This region is the most developed market for sukuk in both primary and secondary market. 
Whereas, Islamic funds also performing very well in Asia and set to grow further with the initiatives of implementing different schemes of Shariah compliant funds (GIFF, 2012). The largest market of Takaful is GCC with US $\$ 6.4$ billion assets, whereas Asia remains the second largest region with total Takaful assets of US\$6 billion. The industry has now achieved significant market share versus conventional insurance in most GCC countries as well as South East Asian markets. There are a number of factors behind this growth but the main reason that is becoming increasingly important is regulatory support through appropriate amendments in legislature to provide a level playing field with conventional insurance companies (Ernst and Young, 2012)

The financial institutions have fully adopted Islamic banking in the Islamic Republic of Iran and Sudan, also the process of full transformation of the financial system to become compliant with Islamic principles is underway in Pakistan. Islamic financing operates along with conventional financing in some other countries, like Malaysia, Indonesia, Bangladesh, Jordan, and Egypt through the opening of Islamic "windows" in conventional institutions or by the establishment of separate banks, or branches and subsidiaries that specialize in Islamic financial products (Khan and Bhatti, 2008; Sundararajan and Errico, 2002).

Table 2: Countries by Largest Shariah-Compliant Assets, US\$ Billion, 2011

\begin{tabular}{|l|c|c|c|c|c|c|c|c|}
\hline Country & Total & Bank & $\begin{array}{c}\text { Tak } \\
\text { aful }\end{array}$ & $\begin{array}{c}\text { Fund } \\
\text { s }\end{array}$ & $\begin{array}{c}\text { Oth } \\
\text { ers }\end{array}$ & $\begin{array}{c}\text { Market } \\
\text { Share } \\
(\%)\end{array}$ & $\begin{array}{c}\text { Muslim } \\
\text { population } \\
\text { (in } \\
\text { Millions) }\end{array}$ & $\begin{array}{c}\text { GDP per } \\
\text { capita } \\
\text { PPP(curre } \\
\text { nt Intl. } \mathbf{\text { ) }}\end{array}$ \\
\hline Iran & $\mathbf{3 8 8}$ & 383.5 & .42 & .3 & --- & $35.7 \%$ & 75 & 11,508 \\
\hline S. Arabia & $\mathbf{1 5 1}$ & 147.8 & .32 & --- & 0.0 & $13.9 \%$ & 25 & 24,268 \\
\hline Malaysia & $\mathbf{1 3 3 . 4}$ & 120.4 & 9.9 & --- & 3.2 & $12.3 \%$ & 17 & 16,051 \\
\hline UAE & $\mathbf{9 4 . 1}$ & 92.5 & 1.5 & 0.0 & .1 & $8.7 \%$ & 5.18 & 47,893 \\
\hline Kuwait & $\mathbf{7 9 . 7}$ & 68.9 & .1 & 10.6 & 0.0 & $7.3 \%$ & 2.21 & 54,283 \\
\hline Bahrain & $\mathbf{5 7 . 9}$ & 56.2 & .4 & 1.3 & --- & $5.3 \%$ & .97 & 23,645 \\
\hline Qatar & $\mathbf{5 2 . 3}$ & 50.0 & .5 & 1.8 & .1 & $4.8 \%$ & 1.58 & 88,314 \\
\hline Turkey & $\mathbf{2 8 . 0}$ & 28.0 & --- & --- & --- & $2.6 \%$ & 75 & 17,110 \\
\hline UK & $\mathbf{1 9 . 0}$ & 19.0 & --- & --- & --- & $1.7 \%$ & 1.7 & 35,657 \\
\hline Sudan & $\mathbf{1 2 . 1}$ & 12.1 & --- & --- & --- & $1.1 \%$ & 31 & 2,325 \\
\hline Bangladesh & $\mathbf{1 1 . 7}$ & 11.4 & .3 & .1 & --- & $1.1 \%$ & 149 & 1,777 \\
\hline Indonesia & $\mathbf{1 0 . 5}$ & 10.0 & .5 & --- & --- & $1 \%$ & 205 & 4,636 \\
\hline Syria & $\mathbf{8 . 7}$ & 8.7 & --- & --- & --- & $.8 \%$ & 21 & 5,252 \\
\hline Egypt & $\mathbf{7 . 9}$ & 7.9 & --- & --- & --- & $.7 \%$ & 80 & 6,281 \\
\hline Switzerland & $\mathbf{6 . 6}$ & 6.6 & --- & --- & --- & $.6 \%$ & .34 & 51,262 \\
\hline Jordan & $\mathbf{5 . 9}$ & 5.7 & .1 & .1 & --- & $.5 \%$ & 5.96 & 5,966 \\
\hline Pakistan & $\mathbf{5 . 7}$ & 5.6 & --- & --- & .1 & $.5 \%$ & 178 & 2,745 \\
\hline Brunei & $\mathbf{3 . 8}$ & 3.8 & --- & --- & --- & $.3 \%$ & .26 & 51,760 \\
\hline $\begin{array}{l}\text { Other } \\
\text { Countries }\end{array}$ & $\mathbf{1 0 . 3}$ & 9.8 & .4 & .1 & 0.0 & $1.1 \%$ & --- & --- \\
\hline Total & $\mathbf{1 0 8 6 . 5}$ & 1047.7 & 20.9 & 14.3 & 3.5 & $100 \%$ & --- & --- \\
\hline
\end{tabular}

*Includes only those firms submitting data to the Banker's survey

Source: UKIFS, 20012; OIC Outlook Series, 2012; World Bank Database, 2012 
At the country level, Table 2 indicates that Iran from MENA region accounts for $35.7 \%$ in total Islamic finance assets. In GCC region, Saudi Arabia accounts $13.9 \%$, United Arab Emirates (UAE) 8.7\%, Kuwait 7.3\%, Bahrain, 5.3\%, and Qatar, 4.8\% of total Islamic financial assets. Additionally, Malaysia in Asia captures a share of $12.3 \%$. Islamic financial institutions operating in these countries are likely to foster the future growth of the industry and its expansion and development to new markets. Islamic finance industry is developing very rapidly in other countries of Middle East such as Turkey, Sudan, Egypt, Jordan and Syria. Nigeria is moving up efforts to capitalize on the Islamic finance industry in SSA region. In Asia, Indonesia and Bangladesh with largest indigenous Muslim population each represent approximately $1 \%$ of the global Islamic finance industry.

Table 2 represents that, Islamic banking assets hold a predominantly higher share in the overall size of the industry in almost all countries where Islamic financial services are available. In contrast, Takaful has comparatively significant presence in countries like Iran, Malaysia, Saudi Arabia and the UAE. On the other hand, in terms of Islamic investment activity, Islamic investment firm assets represent an important portion of the industry's assets in Kuwait (OIC outlook series, 2012). In 2011, the overall volume of Islamic finance assets was recorded at $\$ 388$ billion in Iran, followed by Saudi Arabia ( $\$ 151$ billion), Malaysia ( $\$ 133$ billion), UAE ( $\$ 94$ billion), Kuwait ( $\$ 80$ billion), Bahrain ( $\$ 58$ billion), Qatar ( $\$ 52$ billion), Turkey ( $\$ 28$ billion), UK ( $\$ 19$ billion), Sudan ( $\$ 12$ billion) and Bangladesh ( $\$ 11.7$ billion).

The above discussion indicates that the market for IFPs is skewed in the gulf and North African region while Asia being a good untapped potential. Moreover, the sector is rapidly growing with a major share of banking services as compared to investment or insurance products.

\section{Implication for Business Marketing Practice}

Next 10-15 years offer significant opportunities for the growth and diversification of Islamic finance. The main reasons behind its prospects are: first, Islamic financial institutions have mainly escaped significant damage in the global financial crisis; second, Islamic finance has much potential to diversify into new growth areas such as trade and infrastructure financing in Asia and the emerging markets; and third, Islamic finance can also seek to meet the increased demand for simpler and more transparent products and 'back-to-basics' finance. There are three key managerial implications of the changing landscape of the industry. First, understanding how IFPs differ from CFPs is likely to results in refining marketing strategies of these products. A particular focus on creating awareness among the Muslim consumers regarding religious and commercial viability of IFPs is likely to help capture the market further. For example, the Islamic insurance products market is still at infancy stage based on the fears that it may be in conflict with the Muslim religious belief. IFPs need to be marketed in a Shariah compliant way to attract more customers. Secondly, Asian provides an untapped potential to grow the market for IFPs. The Gulf and North African region constitute about $72 \%$ of the market with just $28 \%$ of the global Muslim population whereas Asia hosts $41 \%$ of the Muslim population with just $22 \%$ share in 
the global market for IFPs. Thirdly, the products which are already high in demand (e.g. banking services) and areas which have a captured a good market share (e.g. Guld and North African countries) show good acceptance of IFPs and thus be focussed further. At the same time products with little market shares (e.g. Takaful insurance) and areas with a large Muslim population (e.g. Asia) provide challenges as well as opportunities to grow.

Islamic finance has to overcome some important challenges in order to increase its share in global finance sector and contribute to cross-border finance (Shanmugaratnam, 2012). In near future, Islamic finance could capture a large share of financial services in several countries by fulfilling the preferences of significant numbers of people, enhancing financial inclusion and intermediation, and contributing mostly to financial stability and development (Mohieldin, 2012). This provides opportunities to managers and researchers to undertake their marketing and research endeavours to capture and understand Islamic financial market more rigorously. In Islamic financial industry, competition is intense to the extent that many Islamic financial windows and fully fledged institutions are being set up globally. Now more options are being introduced for customers around the world that Islamic financial institutions should develop distinctive techniques to attract the market (Smith, 2012).

IFP attributes are considered more important by Muslim consumers indicates an opportunity for marketers to attract their target market segments. Highly religious consumers can be characterised as conservative and are found to attach greater importance to the Shariah-compliant attributes of IFPs. To attract this segment, marketers should highlight Islamic principles in their advertising and promotional strategies, combined with offering attributes valued by religious consumers. However, to what extent does the religiosity of Muslims influence their purchase of IFPs need to be empirically investigated. 


\section{References}

ACC, \& KPMG (2012). Global alignment: bringing consistency to reporting of Islamic finance through IFRS: The Association of Chartered Certified Accountants.

Ahmad, A. R. Y. (2010). Islamic Modes of Finance and the Role of Sukuk. QFinance.

Ahmedji, D. (2011). The Growing Pains of Islamic Finance: Deloitte.

Ali, S. N. (2008). Islamic Finance and Economics as Reflected in Research and Publications. Review of Islamic Economics, 12(1), 151-168.

Ali, S. S. (2011). Isalamic Banking in the MENA Region. The World Bank: Islamic Development Bank- Islamic Research and Training Institute.

Aziz, Z. A. (2012). Islamic finance - new frontiers in financing the economy Paper presented at the Quarterly Financial Panel Discussion 2012.

Banker, T. (2009). Top 500 Islamic Financial Institutions, November.

Billah, M. M., \& Patel, S. (2003). An Opportunity for ICMF Members to Provide Islamic Insurance (Takaful) Products. The International Cooperative and Mutual Insurance Federation (ICMIF) publications.

Doyle, P. (2002). Marketing Management and Strategy (3rd ed.). : England: Pearson Education.

El-Qorchi, M. (2005). Islamic finance gear up. Finance and Development, 42(4), 46-50.

Ernst, \& Young (2012). Industry growth and preparing for regulatory change. Paper presented at the 7th Annual World Takaful Conference

Farquhar, J., \& Meidan, A. (2010). Marketing of Financial Services: Palgrave Macmillan.

Gait, A., \& Worthington, A. (2007). A Primer on Islamic Finance: Definitions, Sources, Principles and Methods. Hyderabad: ICFAI Press.

Gait, A., \& Worthington, A. (2008). An empirical survey of individual customers, business firm and financial institution attitudes towards Islamic methods of finance. International journal of Social Economics, 35(11), 783-808.

Gait, A. H., \& Worthington, A. (2009). A Primer on Islamic Finance: Definitions, Sources, Principles and Methods. Department of Accounting, Finance and Economics, Griffith University.

GIFF (2012). Internationalisation of Islamic Finance: Bridging Economies. Paper presented at the Global Islamic Finance Forum.

Haider, J., \& Azhar, M. (2010). Islamic Capital Market: Sukuk and its Risk Management in the Current Scenario. Umea University, Sweden.

Hamzeh, I. I. (2009). Islamic Finances: Mainstream Alternative to Conventional Finance. Athens Information Technology, Athens, Greece.

IDB (2012). Key Socio-Economic Statistics on IDB Member Countries. Kingdom of Saudi Arabia: Data Resources and Statistics Department, Islamic Development Bank.

IFSB, IDB, \& IRTI (2010). Islamic Finance and Global Financial Stability: Islamic Financial Services Board, Islamic Development Board, Islamic Research and Training Institute: April 2010.

Imady, O., \& Seibel, H. D. (2006). Principles and Products of Islamic Finance. Working Paper, No. 2006-1, Development Research Center, University of Cologne, Germany.

Iqbal, Z. (1997). Islamic Financial System. Finance and Development, 34.

Kahf, M., \& Khan, T. (1993). Principles of Islamic Finance: Research Paper No. 16. Islamic Research and Training Institute, Islamic Development Bank, Jeddah.

Kasper, H., van Helsdingen, P., \& Gabbott, M. (2006). Services Marketing Management: A Strategic Perspective. Chichester, UK: John Wiley \& Sons, Ltd.

Khan, H., \& Bashar, O. K. M. R. (2008). Islamic Finance:Growth and Prospects in Singapore. U21 Global Working Paper Series, No. 001/2008.

Khan, M. M., \& Bhatti, M. I. (2008). Islamic banking and finance: on its way to globalization. Managerial finance, 34(10), 708.

Maurer, B. (2001). Engineering an Islamic Future: Speculations on Islamic Financial Alternatives. Anthropology Today, 17(1), 8-11. 
Mayasami, R. C., \& Kwon, W. J. (1999). An analysis of Islamic Takaful Insurance- A cooperative Insurance Mechanism. Journal of Insurance Regulation, 18(1), 109-132.

Nasr, S. (2011). Islamic Finance in Arab World: Challanges and Prospects. Paper presented at the Cambridge Business \& Economics Conference (CBEC).

NBR (2008). Islamic Finance: Global Trends and Challenges. The National Bureau of Asian Research, 18(4).

Novethic (2008). Islamic Finance and SRI: Any Crossover? Novethic: Working Paper.

Obaidullah, M. (2005). Islamic Financial Service, Islamic Economic Research Centre, King Abdulaziz University, Jeddah, Saudi Arabia

OIC. (2012) Islamic Finance in OIC Member Countries. Ankara, Turkey: Organization of Islamic Cooperation (OIC Outlook Series):SESRIC.

Sundararajan, V., \& Errico, L. (2002). Islamic Financial Institutions and Products in the Global Financial System: Key Issues in Risk Management and Challenges Ahead. IMF Working Paper, Monetary and Exchange Affair Department.

Tayyebi, A. (2009). Eclipse by thr Crescent Moon: Islamic FInance provides some light in the Global Financial Crisis. Financial Services Review, ACCA Global, June.

UKIFS (2012). Islamic Finance. The UK Islamic Finance Secretariat: Gatehouse Bank.

Venardos, A. M. (2006). Islamic Banking and Finance in Southeast Asia: Its Development and Future. Singapore: World Scientific Publishing.

Wilson, R. (1997). Islamic finance and ethical investment. International Journal of Social Economics, 24(11), 1325-1342.

Wyman, O. (2009). The Next Chapter in Islamic Finance: Higher Rewards but Higher Risks.

Zaher, T., \& Hassan, M. K. (2001). A Comparative Literature Survey of Islamic Finance and Banking. Financial Markets, Institutions and Instruments, 10, 155-199. 